\title{
9 Integral ecology, just peace, and mining
}

\author{
Anna Floerke Scheid and Daniel P. Scheid
}

Pope Francis' encyclical Laudato Si' (2015) represents a vital expansion and development of Catholic social teaching on ecology. In particular, "integral ecology" provides a valuable moral framework that can help articulate norms for building a just peace in light of the modern extractive industry. Early Catholic teaching on our moral duties to safeguard the "environment" or "natural environment" traditionally employed a simple, utilitarian approach to nonhuman goods: they should be shared amongst humankind and used to promote human well-being. This initial approach has blossomed into a much more sophisticated theology of creation, and an analysis of the multilayered causes of ecological degradation, encapsulated by Francis as "integral ecology." Integral ecology proposes a broader holistic telos for human interaction with nonhuman plants, animals, ecosystems, and the planet as a whole (and indeed the entire universe). Moreover, integral ecology intersects with Catholic teaching on war and peace and provides the foundation for an ecological expansion of the idea of just peace, yielding an ecological just peace. This essay will proceed in three parts: first, an overview of the main principles of integral ecology; second, a description of the principles and practices that build a just peace; and third, a brief application of integral ecology and just peace to mining.

\section{Integral ecology}

The two central themes of Laudato Si' (Francis 2015) are the Gospel of Creation and integral ecology. The Gospel of Creation outlines the scriptural and theological roots for affirming the goodness of creation and the importance of the non-human world for the human understanding of God and salvation history. The Gospel of Creation provides a key set of theological themes such as seeing creation as an "order of love," affirming the Earth not just as nature but as creation, and perceiving the indwelling of the resurrected Christ in all creatures $(\mathbb{\$} 77,75,83)$. Integral ecology is a synthetic term that formulates an ethical application of the theological claims of the Gospel of Creation and its inextricable connection to social justice and Christian ethics. While all the principles of 
Catholic social teaching are important for addressing a Catholic peacebuilding approach to mining, integral ecology speaks to the shift in moral vision required to address it adequately.

One of the key drivers of the ecological crisis for Pope Francis, and by extension at the nexus of mining and violence, is the technocratic paradigm. Humans have used technology to alter their immediate surroundings for millennia, just as humans have engaged in mining across civilizations for centuries. Yet technology has now become so powerful and seamless in our globalized cultures that it has led to a new way of seeing the world. The "technocratic paradigm" is a one-dimensional approach to the world that encourages people to disregard and overcome natural limits. For all the wonderful gifts it affords, technology, Francis reminds us, is not neutral. Technology creates a physical and mental framework that conditions lifestyles and social relationships. The technocratic paradigm encourages people to see the world as formless, without any inherent guidelines as to how it is to be used. Thus, this way of framing envisions the entire world as open to human mastery, control, and manipulation (\$106-110).

By contrast, the principle of integral ecology configures the world differently, emphasizing reality as holistic, interconnected, and fundamentally relational. Integral ecology stems from the Gospel of Creation and from the theological conviction that the universe is created by a God who is Trinity and essentially relationship $(\$ 240)$. Yet like all principles of Catholic social teaching, integral ecology also belongs to the natural law and is accessible to people of various backgrounds who do not share this same Catholic and Christian understanding of the Creator. Here we will emphasize three aspects of integral ecology.

First, Francis introduces integral ecology as a holistic moral framework. If the central tendency of the technocratic paradigm is to narrow our moral vision, then integral ecology insists on expanding it. We must return to a "broader vision of reality," otherwise all our vast and various storehouses of information and insight can themselves become a "form of ignorance" $(\$ 139)$. Integral ecology begins with and privileges the whole, rather than starting with any particular part, because it posits that the whole and the relationships that form within it are inextricable from understanding the meaning and purpose of each part. Therefore, one cannot look at the world, or more specifically, the question of the value of mining, from the perspective of humanity alone (or worse, from one subset of humanity and its endless desires) without also looking at the whole that enables human beings to exist and to live peaceably and harmoniously with each other and the rest of creation.

Isolating the economic interests of one country over another, or of one segment of the economy, such as mining, vis-à-vis another, may be useful to a degree and for a limited period of time, but only if the overriding context of the whole is elevated throughout and returned to repeatedly. The whole must be considered before any one part is considered in isolation. In a way, 
Francis challenges modern tendencies to consider "nature" or "the environment" as something outside of human beings and human culture. The tendency to separate concerns about the environment from other human concerns, or from economic and political issues, is part of a reductive moral vision. There is only one integrated reality, and we must see humans and non-human creation alike as part of it.

Second, integral ecology posits this broader vision of reality as pervasively interconnected. We cannot entirely separate one part from another because the strands that connect us to each other are innumerable. Again, we can consider the interests of a particular group separate from the health of other groups, but only for a time. Because all creatures are interconnected, any decision or choice made in one area will affect others. We live in a hybrid world insofar as categories like "nature" and "society" are not strictly separate, but interpenetrate one another. Therefore, we cannot, for example, divorce human wellbeing from the wellbeing of the planet as a whole, or social inequities and the violence that can result from them from ecological pressures. "A true ecological approach always becomes a social approach; it must integrate questions of justice in debates on the environment, so as to hear both the cry of the earth and the cry of the poor" $(\$ 49)$. For Francis, the suffering of the poor is connected to the suffering of the planet, and both must be addressed simultaneously. This is one of the central moral claims of Laudato Si.

Integral ecology, which fuses social and ecological justice, introduces salient moral norms like the danger of a "throwaway culture" which reduces the poor and the Earth itself to "rubbish" $(\$ 22)$. We have not adopted a circular approach to our economy in which waste products are reabsorbed into the production of necessary goods. A throwaway culture is the ethical counterpoint to integral ecology, and it signals the need to address the degradation of the Earth and the hardships of the poor simultaneously. Francis particularly highlights the cultural threats faced by indigenous peoples and calls them "the principal dialogue partners" for economic and political elites $(\$ 146)$. Francis's attention to indigenous communities is an intensification of the links between social and ecological injustice, and resultant violence. These links are especially important when assessing the ethical ramifications of mining, since indigenous peoples have long been marginalized from their lands to make room for economic development that does not benefit them. Integral ecology underscores the interrelatedness, and even interdependence, of all Earth's creatures and systems. Likewise, interconnectedness describes issues of poverty, violence, mining, and ecological degradation. We cannot neatly or simply separate economy from culture, social justice from ecological justice, or nation-states from multinational corporations.

Third, integral ecology is relational and is meant to incorporate ecology into the everyday rhythms of human life. For this reason, Francis connects ecological concerns like climate change and biodiversity to the full range 
of human experience and makes them personal. Along with threatened ecosystems and creatures, integral ecology recognizes the threats faced by various cultural heritages. Francis frames integral ecology in this holistic and relational sense by pointing out that it inculcates a sense of belonging: "There is also a need to protect those common areas, visual landmarks and urban landscapes which increase our sense of belonging, of rootedness, of 'feeling at home' within a city which includes us and brings us together. It is important that the different parts of a city be well integrated and that those who live there have a sense of the whole, rather than being confined to one neighborhood and failing to see the larger city as space which they share with others" $(\$ 151)$. Here we see all three aspects of integral ecology: we must begin with the sense of the whole and what brings us together; we must see different parts of the city as connected; and finally this brings to us a deeper sense of our relationships to each other and the world around us, with the goal of helping us feel rooted and "at home" in the world. The integral ecology of everyday life feeds into other principles of Catholic social teaching, such as the common good and solidarity with future generations.

Integral ecology represents an expanded moral vision, the kind necessary to break through the restricting and stultifying lens of the technocratic paradigm. Indeed, Francis points to an ultimate dimension of integral ecology that stretches to the limit of time and space. Creation, recall, is a larger category with a broader meaning than nature, "for it has to do with God's loving plan in which every creature has its own value and significance" $(\$ 76)$. Francis links the Creator's love of every creature to eternity. The church's tradition teaches that all of creation is ordered by God's love, encouraging us to move from the love of the world around us toward the source of this world and the Creator's love. Francis also stretches our sense of time by including the eschatological horizon, referring to the ultimate destiny of all creatures transformed by God $(\$ 243)$.

Integral ecology, then, impels us to consider the consequences of our actions presently and how they may unfold over the centuries. Solidarity with future generations is a sensible virtue in light of the manifold connections we have across time and space. Francis encourages us to see the common good not just of particular nation-states or of the human family but of the planet and the cosmos as well. For many, such a moral vision will prove daunting; bearing in mind our shared eschatological future or the full cosmic import of our choices will not fully or even perhaps partially determine concrete practical political solutions toward peacemaking and social justice. But integral ecology does point to a much wider moral vision, suggesting that real ethical norms and choices ought to be rooted in this broader cosmic worldview if they are to be aligned with the Catholic understanding of a good creation stemming from a loving Creator.

Rooted in the Gospel of Creation, the ethic of an integral ecology unites human and planetary well-being into a common vision. It provides the 
context for other principles of Catholic social teaching, such as the common good, solidarity, and integral human development, as they apply to issues of mining, violence, and peacemaking. By stressing the interrelatedness of humans and nonhumans, and of the suffering of the Earth with the suffering of the poor, integral ecology provides a foundation for discussing ecological debt and the obligations that the Global North has to the Global South when evaluating the relationships at stake in the mining industry and in light of the historical role that mining operations have had in creating current economic and financial imbalances between the Global North and South. Integral ecology is consonant with what scientists tells us is a rapidly changing world, both ecologically and politically. Integral ecology would encourage a comprehensive and scientifically sound plan for properly balancing mining's benefits and harms in a warming world that is accelerating conflict. Now we turn to an area of longstanding Catholic teaching that converges well with Francis' depiction of integral ecology, namely the Christian tradition of "just peace."

\section{An ecological just peace}

The notion of "just peace" has been developed in Judeo-Christian tradition over the course of millennia. In the New Testament, a just peace is the aim of Jesus' efforts to usher in the Reign of God. In God's reign "the poor [will] no longer be poor, the hungry [will] be satisfied, and the oppressed [will] no longer be miserable" (Nolan 1976, 58). To live out the Reign of God is to live a just peace, sharing our possessions, serving the "least" of God's people, and loving our neighbors as we love ourselves. This just peace envisioned by Jesus as he preached the Reign of God has roots in the biblical notion of shalom, the deep peace articulated in the Hebrew Bible, founded on right, or just, relationships between humankind and God, amongst humans themselves, and between human beings and the rest of God's creation. This last component is mostly latent and undeveloped in the church's tradition, but it bespeaks the potential for the tradition of just peace to dovetail with Francis's "integral ecology." Both integral ecology and just peace are rooted in foundational Christian theological principles of the goodness of creation and the central message of the Kingdom of God, and so they can combine to contribute to peacebuilding in the midst of violence resultant from unjust mining industry practices.

Pope St. Paul VI and Martin Luther King, Jr., contemporaries, were both important figures in bringing the biblical notion of just peace into the political arena in the mid-twentieth century. Their legacy of understanding peace as constitutive of justice remains critical today. Paul VI $(1967, \mathbb{S} 76)$ famously insisted that "peace is not simply the absence of warfare, based on a precarious balance of power; it is fashioned by efforts directed day after day toward the establishment of the ordered universe willed by God, with a more perfect form of justice among men." 
In a similar way, King (1963) responded to those who accused him of fomenting violence by distinguishing between positive and negative peace. The American Civil Rights Movement, with its nonviolent methods of protest and civil disobedience, did not cause tension or violence, but merely surfaced those tensions already present, and absorbed oppressive people's and systems' violent outbursts. While a lack of outright bloodshed may, then, signify a negative peace, King argued that a positive peace is indicated by the presence of justice.

More recently, Christian scholars have refined the concept of just peace considerably (Dennis 2018; Cahill 2019; McCarthy 2020), further arguing that a just peace aims at (a) preventing violence from breaking out in the first place, and (b) defining and refining principles and (c) practices of just peace. The question of mining and peacebuilding suggests the need for a new consideration of the idea of just peace, one that explicitly includes ecological sustainability and restorative justice for the planet. An ecological just peace would insist on the ultimate goal of developing only renewable sources of energy, and on approaches to human dignity and community, work and economics, that begin and accord with the vision of an ecological just peace. The eschatological horizon of integral ecology expands the reasonable timeframe for considering economic decisions, so that while some mining is essential for renewable energy, the consequences for this activity, which stretch out into centuries, must be factored in. The burden of proof for justifying the ecological harms of mining must be made against this ethical backdrop, making short term financial gains increasingly difficult to warrant. Accordingly, in the next section, we explore emerging ideas about just peace, and their salience for establishing an ecological just peace.

\section{Prevention}

A just peace establishes mechanisms for preventing violence from breaking out in the first place, and interrupts cycles of violence. Just peacemaking theory (JPT) consists of ten practices meant to stave off war or violence (Stassen 2008). One resonates deeply with integral ecology: foster just and sustainable economic development. This practice aims to prevent violence and maintain a just peace through locally controlled economic development. "Commitment to the sustained well-being of human beings everywhere, and of their local, regional, national, and global communities is vital to justice and peace and to care of the earth...in sum, justice and peace are closely bound together with sustainable development" (Bronkema, Lumsdaine, and Payne 2008, 134-35). JPT authors suggest that the most successful sustainable development efforts happen at the microlevel with the help of non-governmental organizations. This presents an obvious challenge to any mining industry model that privileges large corporations as potential partners with national governments in sustainable development to the exclusion of smaller and more locally sourced enterprises. 
The prevalence of arrangements in which national governments contract with multinationals to extract resources in discrete regions with little input from local leaders leads scholar Philippe Le Billon $(2008,346)$ to argue that "studies of resource-related conflicts need to broaden their analysis beyond spaces of resource exploitation to include the interrelationship between spaces of production, consumption, representation, and governance." In other words, fostering an ecological just peace requires attention not only to land, but to the nexus of land, culture, politics, and government. Le Billon's remark echoes the inter-relationality so critical to Francis's notion of integral ecology described above. Similarly, Peter Knox (2015) points to the challenges of conducting mining justly by highlighting the lingering effects of colonialism and apartheid in South Africa. The South African regime heavily subsidized white people, for example by granting mineral rights to landowners, but only allowed thirteen percent of land to be owned by black South Africans (121). Randy Odchigue (2015) notes a similar problem in the Philippines, where mining not only threatens biodiversity hotspots but also disenfranchises indigenous peoples, who are among the poorest, of their identity and culture. "The mining industry of the Philippines has yet to show an example of a community that justly and sustainably thrives after its resources are extracted and exported to other countries in the world. This example reveals how degradation of the environment is directly proportional with the exploitation of the poor" (171-72). In this book, Elias O. Opongo's chapter on mining governance and the challenges of equitable distribution of mining profits argues for including local populations in policy-setting processes in order to achieve development that truly improves communities' standards of living.

At the same time, it is important to be mindful that this JPT practice of fostering just and sustainable economic development was articulated prior to Francis's discussion of integral ecology. Along with other pleas for "sustainable development," it has been critiqued as possibly damaging to the environment. For example, the co-author of this essay has drawn on the work of Leonardo Boff to argue that peacebuilding requires not so much new development as virtuous practices of "dignified subsistence" (D. Scheid 2012). Furthermore, the language of "development," especially when it arises from Western contexts, may simply be too embedded with violent colonial and neocolonial assumptions to be helpful for fostering local leadership in indigenous contexts. This just peacemaking principle, then, remains important for preventing violence, but it ought to be expanded further through dialogue with integral ecology, decolonial theory, and indigenous local leadership in discrete contexts.

In light of this discussion of sustainable development and just peace, then, several difficult questions must be considered if we want to promote an ecological just peace. Considering intensifying climate change, tailings dam collapses, acid mine drainage, and other forms of environmental harms, to what degree must any understanding of the concept of "just 


\section{Anna Floerke Scheid and Daniel P. Scheid}

peace" require ecological sustainability? More specifically, can the mining industry develop in any way that is truly both just and sustainable? Modern mining processes seem to match Francis's critique of the technocratic paradigm in terms of the control and domination of the land, and concomitant efforts to dominate the poor. In this way, there is often an inherent violence on ecological systems and indigenous people within some mining systems that themselves help constitute part of the ecological crisis. Given the telos of integral ecology which seeks healthy long-term relationships amongst human beings, the natural world, and planetary systems, how might the mining industry modify its practices in order to contribute to the transition to a truly just and sustainable economic system? There are, for example, efforts at long-term containment of waste following mine closures and at the restoration of sites by modern mining companies (see, for example, ICMM n.d.). An ecological just peace supports these efforts but also critically evaluates them by setting the goal of fully sustainable and renewable practices, with an ethical horizon of millennia rather than decades. Mining must move beyond mere legal compliance or responding to immediate social concerns and set for itself this broader and more substantive standard for action.

\section{Principles}

Catholic scholars have begun to name principles that undergird a just peace. Maryann Cusimano Love (2010, 56-57) enumerates several principles which she calls "norms of just peace" that function in ways akin to and inspired by the criteria of the Christian just war tradition. Love suggests that all Catholic peacebuilding ought to include: just cause, that is defending human dignity and the common good; right intention toward a positive peace; participatory processes, or making room for all stakeholders to contribute to peacebuilding efforts; restoration of social relationships; reconciliation, understood as addressing and acknowledging the harms of violence; restoration of infrastructure; and sustainability, developing structures that can help peace endure over time. Combining Love's principles and Francis's integral ecology, we suggest two foundational principles for an ecological just peace: respect and restoration.

\section{Respect}

Drawing on Love's principles of just cause, participatory process, and sustainability, and Francis's $(2015, \mathbb{2 2}$ ) critique of the technocratic paradigm and a throwaway culture which dismisses the dignity of others on behalf of convenience, we argue that just peace is built on a foundation of respect. Its ground is the innate dignity that accrues to every creature by dint of its relationship to the Creator, while there also remains a particular elevated dignity for human beings (Francis 2015, \$65, 69). This respect 
must be built up through both horizontal and vertical dimensions of social life, reaching not only large governmental and multinational organizations, but also impacting communities and personal daily decisions. Ideally integral ecology and an ecological just peace become a kind of culture, and thus an expectation, that is participatory and intergenerational.

An ecological just peace rooted in respect rejects piecemeal responses to discrete environmental crises, and to communities' concerns about such crises. "Ecological culture cannot be reduced to a series of urgent and partial responses to the immediate problems of pollution, environmental decay and the depletion of natural resources" $(\mathbb{S 1 1 1})$. In the same way, an ecological just peace cannot simply react to discrete outbreaks of violence that result from discrete extractive practices. Rather, an ecological just peace must imbue entire cultures: "There needs to be a distinctive way of looking at things, a way of thinking, policies, an educational programme, a lifestyle and a spirituality which together generate resistance to the assault of the technocratic paradigm" $(\$ 111)$. A peace that is built with justice and is truly ecological is committed to building a society that respects the common good, or the well-being of the community itself; the dignity of each human being; and the well-being of the planet, its resources, creatures, and ecosystems, or the "splendid universal communion" of all creatures $(\$ 220)$. This final element returns to Francis's holistic and cosmic vision, which spreads far wider than the technocratic paradigm and its emphasis on piecemeal reactions as extractive-related violence and other crises explode.

\section{Restoration}

Second, drawing on Love's (2010) principles of right intention, reconciliation, restoration, and, again, sustainability, and Francis's advocacy for ecological education, we note that a just peace is ordered toward restoration. This restoration depends upon the foundational principle of respect. Moreover, restoration is comprehensive of shalom, meaning that it applies to relationships among human beings; between individual human beings and God, as well as human communities and God; and finally, between human beings and creation. Francis $(2015, \$ 210)$ calls for an ecological education that honors and restores harmony among the various relationships among human beings and the planet: "[An ecological education] seeks also to restore the various levels of ecological equilibrium, establishing harmony within ourselves, with others, with nature and other living creatures, and with God." Harms to individual persons, to human communities, to human infrastructure, and to ecosystems must all be acknowledged and repaired as best as possible for a sustainable and ecological just peace to take root and flourish. Many communities have cleaned rivers, restored forests, beautified landscapes, and enhanced urban settings with creative buildings; "these achievements do not solve global problems, but they do show that men and women are still capable of intervening 
positively. For all our limitations, gestures of generosity, solidarity, and care cannot but well up within us, since we were made for love” $(\$ 58)$.

Restoration also includes holding accountable corporations that share responsibility for violence related to mining. Some human rights lawyers suggest "a hierarchy of three forms of corporate complicity in order to distinguish the different ways ... companies might be held accountable for violations from which they ultimately derive an advantage" (Hilary 2017, 81). These are silent complicity-when a corporation "fails to speak out" about violence affecting the areas in which they operate; beneficial complicity-when a corporation "is the beneficiary of" violence done by state or militia forces; and finally direct complicity-when a corporation "provides assistance" to other people or groups knowing they are likely to commit violence. Understanding various forms of complicity in violence is critical to grasping how corporations are involved in harm to people and communities, developing mechanisms for holding them accountable, and envisioning how they can work to make amends.

\section{Practices}

It is helpful to identify practices that promote the principles of respect and restoration, and thus an ecological just peace. Our discussion here is far from comprehensive, but it provides a trellis up which the vines of ecological justice may grow and flower. We discuss nonviolent direct action, trust-building, imaginative thinking, and indigenous peacebuilding. We close this section with a recent example of a community struggling to enact an ecological just peace.

\section{Nonviolent direct action}

Peace studies scholars from multiple disciplines have been reminding us of the relative effectiveness of nonviolent direct action (Chenoweth and Stephan 2011; Nepstad 2011). Nonviolent direct action is actually an umbrella term for a number of resistance practices that address injustice without resort to violence, including marches, rallies, protests, boycotts, and civil disobedience. Nonviolent direct action as a means of surfacing and confronting serious injustices is more promising than armed action because it leads to comparatively fewer harms (particularly in the form of death, serious injury, torture, etc.). As King (1963) explained, these actions do not create discord and violence but expose the injustice and implicit violence that was present throughout and that those who benefit from or are not subject to structural violence often prefer to ignore (see Ethicists Without Borders 2019).

Nonviolent direct action is already a major feature of resistance to ecological injustice and mining-related violence around the globe. Arce and Moran (2020) detail the program of nonviolent direct action motivated by 
fears of ecological damage at the Tía María copper mines in Peru. There, nonviolent direct action helped push both the government and mining project developers to include the local community more robustly in negotiation processes (i.e., respect), ultimately leading the government to delay the mine's opening to 2024. Efforts to ensure a participatory democratic process around the copper mine continue (81-85), and the chapter in this book by José Bayardo Chata Pacoricona details how Derechos Humanos y Medio Ambiente-Puno focuses on legal action in other cases in Peru as a form of nonviolent direct action to avoid having protest situations reach a point where violence can occur.

\section{Trust-building}

An ecological just peace depends on building trust among stakeholders. Lisa Sowle Cahill (2019) argues that trust-building involves holding those responsible for harm accountable (i.e., restoration), as well as shared "activities together around shared goals." Such shared activities and shared goals are critical for the "practical validation of social trust" amongst people and communities in conflict (340). Similarly, Francis $(2015, \$ 213)$ calls for everyone to be involved in ecological education, from individuals and families, to churches, schools, businesses, and governments. Each has a role to play in creating a "a culture of shared life." Laws, however valuable and important, can only be effective in the long term if there are a sufficient number of people who are prepared to accept them $(\$ 211)$. Actions of beautifying, protecting, and restoring public places that belong to everyone (i.e., respect and restoration) are important because through them "relationships develop or are recovered and a new social fabric emerges. Thus, a community can break out of the indifference induced by consumerism. These actions cultivate a shared identity, with a story which can be remembered and handed on" (\$232). Practices that build trust can contribute to a culture of shared life and to people who become ready to adopt new laws and regulations.

\section{Imaginative thinking}

Many scholars point to the importance of nourishing individual and collective human imagination in order to promote just peace. Preeminent peace studies scholar John Paul Lederach $(2005,172)$ urges:

[I]f we are to survive as a global community, we must understand the imperative nature of giving birth and space to the moral imagination.... We must face the fact that much of our current system for responding to deadly local and international conflict is incapable of overcoming cycles of violent patterns precisely because our imagination has been corralled and shackled by the very parameters and sources that create and perpetrate violence. 


\section{8}

Both respect and restoration depend on the capacity to think imaginatively in order to break out of entrenched cycles of violence and vengeance. In a similar vein, Robert Schreiter $(2010,221)$ notes that "the capacity to imagine peace, that is, to think differently about the conflict situation in order to come to new possibilities that might end the conflict, is now being recognized as one of the most important qualities of a peacebuilder."

This emphasis on imaginative thinking suggests that practices for building an ecological just peace will include, in Cahill's $(2019,332)$ words, "song, story, art, and ritual" that contribute to the "transformation of imaginations and worldviews so that a different reality is grasped as truly possible." How might artists, poets, musicians, and playwrights help restore and enrich our understanding, for example, not only of the efficiency and sustainability of renewable energy, but also the sheer beauty of it? Solar panels turn sunshine into our softly glowing baby monitor, so that the light that brings life to the planet also illuminates the doubts and fears of new parents and helps them feel secure. Turbines harness the wind rolling across the ocean to power an electric respirator, so that the invisible force of air itself breathes life into a critically ill patient.

Adjacent to these artistic ideas is the social imaginary of Catholicism itself. Schreiter $(2010,221)$ defines the social imaginary as "framed by certain assumptions about the world and certain rules of connection and communication...filled with certain values, images, and practices." How might Catholic imaginative thinking shape our capacity to envision and then build an ecological just peace? Here the Gospel of Creation is helpful. It posits Catholic imagination as fundamentally ecological, and provides ways of conceiving the nonhuman nature in all its variety as integral to human self-understanding and our relationship to the divine. Francis (2015, \$96-98) imagines Jesus's relationship to the natural world, attentive to the beauty of the Earth and the loveliness of even the smallest creatures, living in harmony with all of nature. For Francis, Jesus embodies integral ecology, fusing a concern for justice and peace with a love for creation and the Creator from whom all things come.

\section{Indigenous peacebuilding}

Finally, an ecological just peace must include robust efforts to draw on values, beliefs, and peacebuilding practices indigenous to the locales in which the efforts occur. For issues related to mining violence, this will mean building and recognizing leadership amongst grassroots peacemakers who understand well the indigenous culture and its conflict transformation practices. Such practices often include reverence for or relationship with elements of the natural world (i.e., respect) and explicitly promote restoration. In Liberia, the palaver "is a ritualized practice of dialogue and communication, which enables the community to come to consensus around ethical norms and the resolution of conflicts" (A. Scheid 2012, 35). 
This peacebuilding ritual often takes place under the community's "palaver tree," sacred ground for people to gather, discuss their differences, and restore justice. Liberians turned to the palaver in their struggle to embrace a just peace in the aftermath of a war that decimated communities through the use of child soldiers (Cahill 2019, 333).

Similarly, Rwandans have been using traditional Gacaca Courts to hold accountable those who participated in the 1994 genocide. The word "gacaca" simply means "a soft green bed of grass," and it is in such natural locations that the community gathers to ritually discuss and resolve conflicts. Gacaca Courts emphasize restorative justice and interpersonal and social reconciliation. Over two million Rwandans have been tried in Gacaca Courts since the genocide. Likewise, South Africa wrote the principle of ubuntu into its first democratic constitution in 1994, and promoted it through the Truth and Reconciliation Commission in the aftermath of apartheid. Ubuntu is a Southern African humanistic philosophy that emphasizes the social nature of the person, and the interdependence of the human community based on respect for our shared humanity. It translates roughly as "a person is a person through other persons," and it continues to be a vital force in South Africa for cultivating a culture that will value justice and peace as part of ongoing healing from apartheid.

\section{El Salvador: a recent example of ecological just peacemaking}

A recent example of a community struggling to enact an ecological just peace that honors the moral vision of integral ecology is the effort to ban metallic mining in El Salvador that is detailed in the chapter of this book by Andrés McKinley. In 2017, legislation passed that banned metallic mining following years of community efforts at organizing and raising awareness. Like many Central American countries, El Salvador has experienced centuries of mining and extractive operations conducted by foreign powers. Despite being among the poorest and most densely populated countries in the Western Hemisphere, and after suffering decades of violence and political repression, the people of El Salvador organized to ban metallic mining for a variety of concerns but primarily because of the effects on the quantity, quality, and access to safe water. McKinley describes how El Salvador is in the midst of a water crisis, and how climate change will only intensify the causes in the coming decades. Metallic mining requires huge stores of freshwater, and mining contaminates water in a variety of ways, most problematically acid mine drainage.

As McKinley observes, opposition to metallic mining in El Salvador evolved over seventeen years, and the many stages of this effort incorporated various elements of an ecological just peace. It began in 2000 with the growing presence of transnational mining companies. Local communities were already poised to respond because of their social bonds forged through years of resistance to companies prospecting for gold and 
silver and through their shared heartbreak during the brutal civil war. From the beginning, the Catholic Church was involved in galvanizing local communities to employ nonviolent means to resist foreign mining interests. The Jesuit-led University of Central America (UCA) conducted research that provided an extensive foundation of information on the long-term effects of the mining operations. Once a legal bill, developed in partnership with environmental experts at UCA, was proposed, the Catholic Church helped lead a massive street march in 2017 to persuade legislative leaders to pass it. When it passed, El Salvador became the first country to ban this form of mining.

El Salvador's resistance demonstrates key features of an ecological just peace: forging diverse coalitions through relationship building over a period of many years; using religiously inspired values and an expansive moral imagination to generate a public consensus; disseminating information and countering propaganda campaigns by foreign companies; and protesting nonviolently in the streets to garner the attention of elected leaders. The seventeen-year-long struggle provides a powerful example of how nonviolent direct action, coalition building, and the Catholic imagination motivated by a moral vision analogous to integral ecology, can promote and further an ecological just peace.

\section{Ecological just peace and mining}

The mining industry is diverse and multifaceted, and each mining enterprise has its own particular set of concerns, such as the target material of the extraction and the method used to extract it, the land it operates on, the historical and political context of the people who live there, the ecosystems of the region, the expectations of the particular extractive companies, etc. This essay has provided a general ethical framework that can situate particular extractive operations in a comprehensive Catholic moral vision, yet we can still draw some brief conclusions from this expansive perspective.

Any process of mining that is not rooted in a broad frameworklike integral ecology-with a deep moral horizon will likely thwart efforts toward an ecological just peace. As Francis contends, modernity is pervaded by a technocratic paradigm, and this includes our appetite for extractives. Absent resistance, extractives will contribute to an intensification of a throwaway culture with its attendant waste, violence, and needless death. While the paradigm of integral ecology stresses a holistic, interconnected, and fundamentally relational framework of human-Earth relationship, the absence of an ecological just peace will lead to greater violence against ecosystems, the poor, and future generations. Without the model of integral ecology, land, ecosystems, and often even people are treated as parts that can be utilized and profited from, consumed or used to varying degrees, and then disposed of. Indigenous populations that stand in the way of development can be 
easily bypassed unless their voice is intentionally privileged and welcomed. In turn, environmental degradation and resource scarcity will become further causes of injustice, setting up cycles of ecological degradation, social conflict, and violence.

An ecological just peace draws on the principles of respect and restoration that undergird peacebuilding practices of nonviolent direct action, trust-building, imaginative thinking, and indigenous practices of reconciliation and restoration. This ethic involves appreciating the relationship of all creatures and ecosystems to their Creator, before measuring the economic utility of extraction; assessing and cataloguing the interrelatedness of an ecosystem and its people and predicting possible implications; valuing the long-term economic, psychological, emotional, and social benefits that come from a healthy and sustainable ecosystem; and welcoming input from local peoples and making them partners in decision making. The moral vision of integral ecology yields a framework for an ecological just peace that can help mitigate violent conflict and other forms of injustice in contexts of mining.

\section{References}

Arce, Moisés, and Riley Moran. 2020. "Extractive Conflicts in the Developing World." Journal of International Affairs 73, no. 2: 77-94.

Bronkema, David, David Lumsdaine, and Rodger A. Payne. 2008. "Foster Just and Sustainable Economic Development." In Just Peacemaking: The New Paradigm for the Ethics of Peace and War, edited by Glen Stassen, 132-152. Cleveland, $\mathrm{OH}$ : The Pilgrim Press.

Cahill, Lisa Sowle. 2019. Blessed Are the Peacemakers: Pacifism, Just War, and Peacebuilding. Minneapolis: Fortress Press.

Chenoweth, Erica, and Maria J. Stephan. 2011. Why Civil Resistance Works: The Strategic Logic of Nonviolent Conflict. New York: Columbia University Press.

Dennis, Marie. 2018. Choosing Peace: The Catholic Church Returns to Gospel Nonviolence. Maryknoll, NY: Orbis.

Ethicists Without Borders. 2019. "Christian Ethics, Climate Emergency, and Nonviolent Direct Action.” June 9, 2019. https://dailytheology.org/2019/06/09/ statement-of-ethicists-without-borders-christian-ethics-climate-emergency-andnonviolent-direct-action/.

Francis. 2015. Laudato Si'. http:/www.vatican.va/content/francesco/en/encyclicals/ documents/papa-francesco_20150524_enciclica-laudato-si.html.

Hilary, John. 2017. The Poverty of Capitalism: Economic Meltdown and the Struggle for What Comes Next. London: Pluto Press.

ICMM. n.d. "Integrated Mine Closure-Good Practice Guide.” Accessed May11, 2021. https:/guidance.miningwithprinciples.com/integrated-mine-closure-goodpractice-guide/.

King, Martin Luther, Jr. 1963. Letter from a Birmingham Jail. http://www.africa. upenn.edu/Articles_Gen/Letter_Birmingham.html.

Knox, Peter. 2015. "Sustainable Mining in South Africa: A Concept in Search of a Theory." In Just Sustainability: Ecology, Technology, and Resource Extraction, 


\section{Anna Floerke Scheid and Daniel P. Scheid}

edited byChristiana Z. Peppard and Andrea Vicini, 117-130. Maryknoll, NY: Orbis.

Le Billon, Philippe. 2008. "Diamond Wars? Conflict Diamonds and Geographies of Resource Wars." Annals of the Association of American Geographers 98, no. 2: 345-372.

Lederach, John Paul. 2005. Moral Imagination: The Art and Soul of Building Peace. New York: Oxford University Press.

Love, Maryann Cusimano. 2010. "What Kind of Peace Do we Seek? Emerging Norms of Peacebuilding in Key Political Institutions." In Peacebuilding: Catholic Theology, Ethics, and Praxis, edited by Robert J. Schreiter, R. Scott Appleby, and Gerard F. Powers, 56-91. Maryknoll, NY: Orbis.

McCarthy, Eli, ed. 2020. A Just Peace Ethic Primer: Building Sustainable Peace and Breaking Cycles of Violence. Washingon, DC: Georgetown University Press.

Nepstad, Sharon Erikson. 2011. Nonviolent Revolutions: Civil Resistance in the Late Twentieth Century. New York: Oxford University Press.

Nolan, Albert. 1976. Jesus Before Christianity. New York: Orbis Books.

Odchigue, Randy J.C. 2015. "The Ecclesial Contribution to Sustainable Communities." In Just Sustainability: Ecology, Technology, and Resource Extraction, edited by Christiana Z. Peppard and Andrea Vicini, 171-181. Maryknoll, NY: Orbis.

Paul VI. 1967. Populorum Progressio. http://www.vatican.va/content/paul-vi/en/ encyclicals/documents/hf_p-vi_enc_26031967_populorum.html.

Scheid, Anna Floerke. 2012. "Interpersonal and Social Reconciliation: Finding Congruence in African Theological Anthropology." Horizons 39, no. 1 (Spring): 27-49.

Scheid, Daniel P. 2012. "Just Peacemaking Theory and the Promotion of Dignified Subsistence." In Violence, Transformation, and the Sacred: They Shall Be Called Children of God (College Theology Society Annual Volume 2011), edited by Margaret R. Pfeil and Tobias L. Winright, 175-189. Maryknoll, NY: Orbis.

Schreiter, Robert J. 2010. "The Catholic Social Imaginary and Peacebuilding: Ritual, Sacrament, and Spirituality." In Peacebuilding: Catholic Theology, Ethics, and Praxis, edited byRobert J. Schreiter, R. Scott Appleby, and Gerard F. Powers, 221-239. Maryknoll, NY: Orbis.

Stassen, Glen, ed. 2008. Just Peacemaking: The New Paradigm for the Ethics of Peace and War. Cleveland, OH: The Pilgrim Press. 